\title{
Use of a cysteine proteinase from Carica candamarcensis as a protective agent during DNA extraction
}

M.S. Genelhu, M.S. Zanini, I.F. Veloso, A.M.D. Carneiro, M.T.P. Lopes and C.E. Salas

\author{
Laboratório de Biologia Molecular de Produtos Naturais, \\ Departamentos de Bioquímica e Farmacologia, \\ Instituto de Ciências Biológicas, \\ Universidade Federal de Minas Gerais, \\ Belo Horizonte, MG, Brasil
}

\section{Correspondence}

C.E. Salas

Laboratório de Biologia Molecular

de Produtos Naturais

Departamento de Bioquímica e

Imunologia, ICB, UFMG

Av. Antônio Carlos, 6627

31270-901 Belo Horizonte, MG

Brasil

E-mail: cesbufmg@mono.icb.ufmg.br

Research supported by FAPEMIG and CNPq.

\begin{abstract}
We describe the use of a plant cysteine proteinase isolated from latex of Carica candamarcensis as a protective agent during isolation of bacterial DNA following growth in culture of these cells. Between 100 to 720 units of proteinase ( $1 \mu \mathrm{g}=6$ units) afforded good DNA protection when incubated with various kinds of microorganisms. Agarose gel electrophoresis showed that the resulting DNA was similar in size to DNA preparations obtained by treatment with proteinase $\mathrm{K}$. The viability of the resulting material was checked by PCR amplification using species-specific primers. After standing at room temperature $\left(25^{\circ} \mathrm{C}\right)$ for 35 days, the enzyme lost $10 \%$ of its initial activity. The enzyme stability and good yield of DNA suggest the use of this proteinase as an alternative to proteinase $\mathrm{K}$.
\end{abstract} Key words - Cysteine proteinase - Proteinase K - C. candamarcensis - DNA extraction

Many procedures have been developed to facilitate the isolation of genetic material, by inactivating endogenous nucleases (1-3). These protocols must be gentle enough to permit later use of the DNA in techniques such as molecular cloning, enzyme digestion or PCR. One of the most ubiquitous procedures involves the use of proteinase K (4), a $\mathrm{Ca}^{2+}$-dependent enzyme from Tritirachium album that remains substantially active following incubation at temperatures higher than $50^{\circ} \mathrm{C}$ in buffer systems containing $\operatorname{SDS}(5,6)$. In a search for alternative sources of proteolytic enzymes, we isolated a plant cysteine proteinase from Carica candamarcensis. The enzyme has been purified by chro- matography on Sephadex G-10, CMSephadex, and MonoS Sepharose (7). The isolated enzyme, named E6870, was characterized as a single chain protein with an estimated $\mathrm{Mr}$ of $22-24 \mathrm{kDa}$, and behaves like a classic cysteine proteinase (Salas CE, García $\mathrm{O}$ and Mouhm V, unpublished data). The active fractions obtained from the last purification step display proteolytic activity in the $\mathrm{pH}$ range 5.5 to 8.3 . They were concentrated by ultrafiltration through a PM 10 membrane and stored in $0.1 \mathrm{M}$ sodium acetate, $\mathrm{pH} 5.0$, at $4^{\circ}$ or $-20^{\circ} \mathrm{C}$ in the presence of $25 \%$ glycerol. The activity of this concentrated stock remained unchanged for one year at $4^{\circ} \mathrm{C}$.

The amidolytic activity was assayed us- 
Figure 1 - Isolation of DNA from Lepstospira and Mycobacterium with E6870.

A, Leptospira tarasovi $\left(10^{8}\right.$ cells $)$ was sedimented at $14,000 \mathrm{~g}$ for $20 \mathrm{~min}$. The sedimented cells were resuspended in $50 \mathrm{mM}$ Tris, pH 8.0, 50 mM EDTA, 100 $\mathrm{mM} \mathrm{NaCl}, 1 \% \mathrm{SDS}$ and $120 \mathrm{U}$ of proteinase $K$ or $100-400 \mathrm{U}$ of E6870 and the mixture was incubated at $50^{\circ} \mathrm{C}$ for $2 \mathrm{~h}$. The solution was then centrifuged at $10,000 \mathrm{~g}$ for $10 \mathrm{~min}$ and the supernatant deproteinized by phenol extraction (phenol:chloroform: isoamylalcohol $=25: 24: 1$ ) . Before precipitation, $1 \mu \mathrm{g}$ tRNA was added as carrier. After ethanol precipitation and washing with $70 \%$ ethanol the dried pellet was dissolved in $20 \mu \mathrm{l} \mathrm{TE}$ (Tris-EDTA) and $10 \mu \mathrm{l}$ of this solution was electrophoresed on a $1.5 \%$ agarose gel along with molecular weight markers. Lanes: 1, $\lambda$-HindIII; $2,120 \mathrm{U}$ proteinase K; 3, $100 \mathrm{U} ; 4,200 \mathrm{U} ; 5,300 \mathrm{U}$ and 6, $400 \mathrm{U}$ of E6870.

B, Mycobacterium bovis previously inoculated into milk was isolated as follows: a milk sample $(1 \mathrm{ml})$ containing $10^{8}$ $\mathrm{CFU} / \mathrm{ml}$ of $M$. bovis was incubated overnight with $720 \mathrm{U}$ proteinase K (Boehringer, Mannheim, Germany), $360 \mathrm{U}$ (lane 3), or $720 \mathrm{U}$ (lane 4) of E6870 at $56^{\circ} \mathrm{C}$ in buffer $10 \mathrm{mM}$ Tris, 5 mM EDTA, pH 8.0, 1.5\% SDS. The suspension was acidified with $200 \mu \mathrm{l} 10 \%$ acetic acid and proteins were removed with 1 $\mathrm{ml}$ of a mixture containing phenol $(3 x)$ as shown in Figure 1A. The remaining procedure was as described in $1 \mathrm{~A}$. An aliquot $(20 \%$ of total volume) was electrophoresed on agarose gel $(1.5 \%)$ followed by ethidium bromide staining. Lanes: $1, \lambda$-Hindlll; 2 , $720 \mathrm{U}$ proteinase $\mathrm{K} ; 3,360 \mathrm{U}$; 4 , $720 \cup$ E6870; 5, no proteinase added.

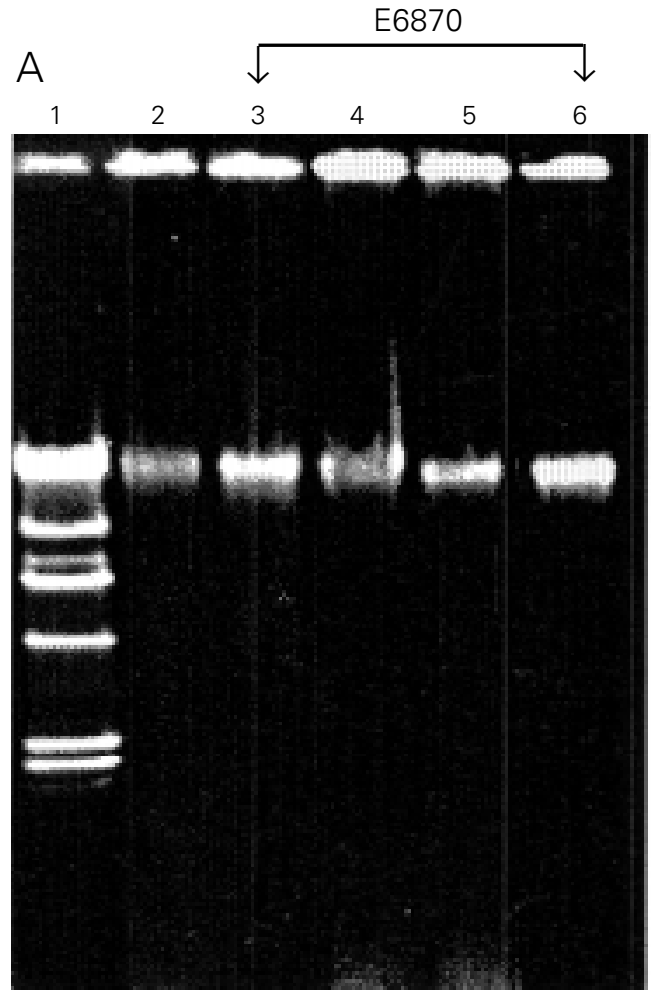

ing benzoyl-arginyl-p-nitroanilide (BAPNA) as substrate (7) and the proteolytic activity using casein as substrate (8). E6870 showed no signs of DNAase or RNAase activity, as indicated by incubation of $106 \mathrm{U}$ of E6870 with $\lambda$ DNA $(0.5 \mu \mathrm{g})$ or $E$. coli tRNA $(5 \mu \mathrm{g})$ at $37^{\circ} \mathrm{C}$ for $24 \mathrm{~h}$, followed by agarose electrophoresis (data not shown).

In this study, we evaluated the performance of E6870 in protocols used to extract DNA from Leptospira and Mycobacterium bovis. The protective effect of E6870 in DNA extracting protocols was compared with that of proteinase K. We used the caseinolytic assay to standardize the amounts of both enzymes used (8). Figure 1A,B shows the data obtained after extraction of Leptospira and Mycobacterium bovis DNA with E6870 or proteinase $\mathrm{K}$. The data show that both E6870 and proteinase $\mathrm{K}$ release Leptospira DNA of similar size and amounts (compare intensity of bands in lane 2 and 3 in Figure 1A). Also, the amounts of DNA recovered with E6870 were similar in experiments carried out to isolate mycobacterial DNA (Figure 1B). The effects of E6870 and proteinase $\mathrm{K}$ were also similar.

However, since we were uncertain about whether the use of E6870 could have an adverse effect, we further checked the intactness of DNA resulting from this extraction by applying the PCR technique. Primers were chosen to amplify specific targets of DNA from the genera Leptospira (9) and Mycobacterium (10).

These experiments are summarized in Figure 2A,B. The amplification profiles of different serovars from Leptospira showed an 849-bp band present in each serovar at 2 $\mathrm{mM} \mathrm{Mg}{ }^{2+}$, although the band intensity varied from isolate to isolate (Figure 2A, lanes 3-8). In addition, a 370-bp band was evident in serovars L. bratislava, L. hardjo, L. norma and L. hardjobovis. The different intensity observed in the 849-bp band from various serovars can be explained by differences in $\mathrm{Mg}^{2+}$ requirement during PCR for each 
serovar. This can be corrected by adjusting the $\mathrm{Mg}^{2+}$ concentration in the PCR of each serovar to its optimal value (data not shown).

In a second group of experiments, we applied the PCR technique to identify $M$. bovis in milk samples from animals suspected of being infected. The screening revealed that PCR obtained from milk samples from two animals (see Figure 2B, lanes 3 and 7) were positive ( $383 \mathrm{bp}$ ), while those from the remaining animals were negative. The negative results in Figure 2B are not caused by a selective loss of bacterial DNA during DNA extraction since each sample was shown to contain similar amounts of total DNA by agarose electrophoresis before PCR (data not shown). To our knowledge, this is the first time that $M$. bovis was identified directly in milk samples from cattle by PCR. A full report on this technique is being published elsewhere (11).

The present data show that E6870 from C. candamarcensis represents a good option during isolation of bacterial genomic DNA. One of the advantages is the stability of E6870 since thermal inactivation of the enzyme was less than $10 \%$ following a 35 -day incubation period at room temperature (data not shown). The lack of divalent cation requirements in E6870 is another advantage compared to proteinase $\mathrm{K}$, the calcium protein most widely used in nucleic acid extractive protocols. Therefore, E6870 performs well in mixtures containing 5-15 mM EDTA, thus improving the inhibition of nucleases that otherwise could degrade their target.

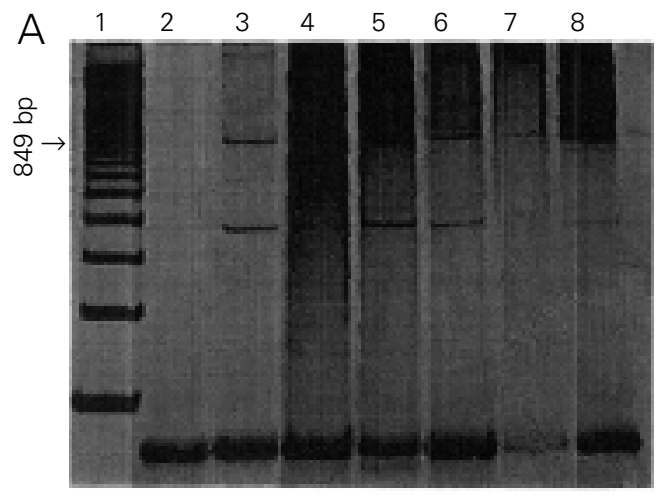

Figure 2 - PCR amplification of DNA from Leptospira and Mycobacterium.

A, DNA (10 ng) from Leptospira was subjected to 30 amplification cycles consisting of denaturation at $94^{\circ} \mathrm{C}$ for $90 \mathrm{~s}$, annealing at $58^{\circ} \mathrm{C}$ for $90 \mathrm{~s}$ and extension at $72^{\circ} \mathrm{C}$ for $2 \mathrm{~min}$. The last extension step lasted $10 \mathrm{~min}$. The other components of the mix were: $2 \mathrm{mM} \mathrm{MgCl}_{2}, 0.2 \mathrm{mM}$ dNTP, $50 \mathrm{mM} \mathrm{KCl}, 10 \mathrm{mM}$ Tris$\mathrm{HCl}, \mathrm{pH} 8.0,0.1 \%$ Triton $\mathrm{X}-100$, $10 \cup$ Taq polymerase and 800 nM each of primers Lep13/ Lep14 (9). Lane 1, 100 bp; lane

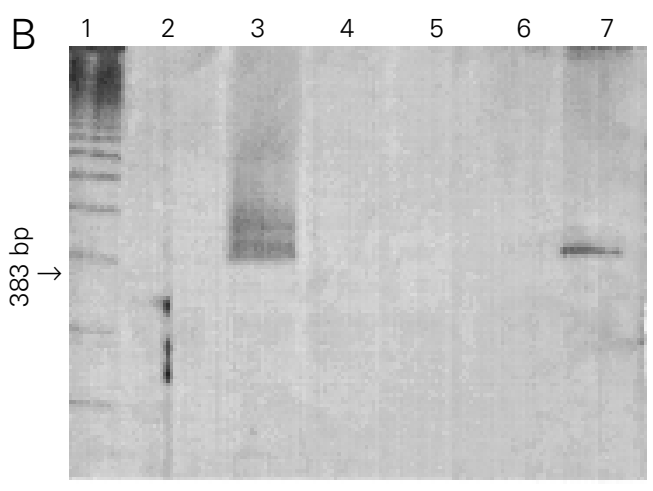

2 , negative control; lanes 3-8 are L. bratislava, L. hardjo, L. norma, $L$. hardjobovis, L. mini, and $L$. neguita, respectively.

$B$, Mycobacterial DNA 10.001 $500 \mathrm{ng})$ was subjected to 42 cycles of amplification consisting of denaturation at $95^{\circ} \mathrm{C}$ for $30 \mathrm{~s}$, annealing at $68^{\circ} \mathrm{C}$ for $60 \mathrm{~s}$ and extension at $72^{\circ} \mathrm{C}$ for $30 \mathrm{~s}$. The final extension step was carried out at $72^{\circ} \mathrm{C}$ for $30 \mathrm{~min}$. The other components of the mixture were: $50 \mathrm{mM} \mathrm{KCl}, 10 \mathrm{mM}$ Tris, $\mathrm{pH} 8.3,2.0 \mathrm{mM} \mathrm{MgCl}_{2}, 0.2$ $\mathrm{mM}$ each of dATP, dCTP, dGTP and $0.4 \mathrm{mM}$ dUTP or dTTP, 0.5 $\mu$ mol each of primers BW6/BW7 $(10,12), 0.5 \cup$ of uracil DNA glycosylase (Gibco BRL, Gaithersburg, MD), and $2.5 \cup \mathrm{Taq}$ DNA polymerase. Before PCR the mixture was preincubated at $37^{\circ} \mathrm{C}$ for $10 \mathrm{~min}$. The glycosylase was then heat inactivated by incubation at $95^{\circ} \mathrm{C}$ for $10 \mathrm{~min}$. Lane 1, $100 \mathrm{bp}$; lanes 2-7 are DNA from cow's milk collected from different animals.

\section{References}

1. Wilson K (1996). Preparation of genomic DNA from bacteria. In: Asubel FM, Brent R, Kungston RE, Moore DD, Seidman JG, Smith JA \& Struhl K (Editors), Current Protocols in Molecular Biology. Vol I. John Wiley and Sons, Massachusetts, 242-245.

2. Favaloro J, Treisman R \& Kamen R (1980). Transcription map of polyoma virus specific RNA: Analysis by two dimensional nuclease S1 gel mapping. Methods in Enzymology, 65: 718-723.

3. Bowtell DDL (1987). Rapid isolation of eukaryotic DNA. Analytical Biochemistry, 162: 463-467.

4. Ebeling $W$, Hennrich N, Kclockow M, Metz H, Orth HD \& Lang H (1974). Proteinase $\mathrm{K}$ from Tritirachium album Limber. European Journal of Biochemistry,
47: 91-97.

5. Blin N \& Stafford DW (1976). A general method for isolation of high molecular weight DNA from eukaryotes. Nucleic Acids Research, 3: 2303-2307.

6. Finne J \& Krusius T (1982). Preparation and fractionation of glycopeptides. Methods in Enzymology, 83: 269-277.

7. Moraes MG, Termignoni C \& Salas $C$ 
(1994). Biochemical characterization of a new cysteine endopeptidase from Carica candamarcensis L. Plant Science, 102: 1118.

8. Baeza G, Correa D \& Salas CE (1990). Proteolytic enzymes in Carica candamarcensis. Journal of the Science of Food and Agriculture, 51: 1-9.

9. Woodward MJ \& Redstone JS (1993). Dif- ferentiation of leptospira serovars by the polymerase chain reaction and restriction fragment length polymorphism. Veterinary Record, 132: 325-326.

10. Wards BJ, Collins DM \& Lisle GW (1995). Detection of bacterium bovis in tissues by polymerase chain reaction. Veterinary Microbiology, 43: 227-240.

11. Zanini MS, Moreira EC, Lopes MTP, Mota
P \& Salas CE (1998). Detection of Mycobacterium bovis in artificially infected milk by polymerase chain reaction. Journal of Veterinary Research $B$ (in press).

12. Willens $H$, Thiele $D$, Frolich-Ritter $R$ \& Krauss H (1994). Detection of Coxiella burnetti in cow's milk using the polymerase chain reaction (PCR). Journal of Veterinary Methods, 41: 580-587. 